\title{
Learning during the covid-19 pandemic: Analysis of e-learning on sports education students
}

\author{
Aditya Gumantan* $^{*}$, Reza Adhi Nugroho ${ }^{\mathbb{1}}$, Rizki Yuliandra \\ Universitas Teknokrat Indonesia, Indonesia
}

Received: 04 August 2020; Accepted 05 January 2021; Published 07 February 2021

Ed 2021; 6(1): 51-58

\begin{abstract}
This study aims to determine the level of achievement in each competency given to students and to find out the average percentage of post-e-learning student scores. The research method used is quantitative with descriptive statistical techniques. The study population is sports education students in class 2017, 2018 and 2019, active students, with a sample of $10 \%$ of the population, the determination of this sample is based on purposive sampling. Data collection techniques use test instruments, in the form of questions and semester exam results. The research data analysis technique uses descriptive statistical techniques obtained during the 2019-2020 semester, namely the value of the Final Semester Examination, after feeling that it is sufficient to obtain data and process it will get the results of the research. The results of the study find that effective learning is seen from $83 \%$ of students getting course scores with an average of above 75 at the time of the final even semester examinations in 2019-2020, and it can be concluded that the effectiveness of e-learning in Sports Education students at the Indonesian Teknokrat University is successful. with a student passing rate above $80 \%$. It is hoped that this e-learning process will be further developed with a better platform for the sake of facing future generations where the role of technology is a major thing in facing the changing times.
\end{abstract}

Keywords: Learning; covid-19; analysis; e-learning; sports education

d.

https://doi.org/10.25299/sportarea.2021.vol6(1).5397

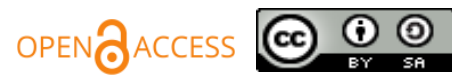

Copyright (C) 2021 Aditya Gumantan, Reza Adhi Nugroho, Rizki Yuliandra

Corresponding author: Aditya Gumantan, Sport Education, Universitas Teknokrat Indonesia, Bandar Lampung, Lampung, Indonesia

Email: aditya.gumantan@teknokrat.ac.id

How To Cite: Gumantan, A., Nugroho, R. A., \& Yuliandra, R. (2021). Learning during the covid-19 pandemic: Analysis of elearning on sports education students. Journal Sport Area, 6(1), 51-58. https://doi.org/10.25299/sportarea.2021.vol6(1).5397

\section{INTRODUCTION}

Education is part of the process of increasing the competence of everyone, changing from not knowing to knowing and changing the integrity of the people themselves. Peraturan Pemerintah Republik Indonesia Nomor 47 (2008) explained that Indonesia has arranged an education curriculum with a tiered system and is regulated with the slogan of compulsory nine years of education, nine years of compulsory education with a six-year scheme of elementary school, junior high school for three years and senior high school for three years. At the state level, it has been clearly regulated how the education process realizes increased competence by seeing graduates in each level of education itself by involving experts in managing the curriculum that is made, the curriculum is broken down again into annual programs, semester programs, syllabus, and learning program plans. Education is a conscious effort carried out by families, communities and the government which has one goal in the form of guiding, teaching and training that takes place at school or outside of school. (Suryani \& Sudarso, 2017). In various aspects of the objectives are put forward by the inner state secretariat Hermawan and Kintamani (2015) education is developing in terms of the 
potential of students to become human beings who are pious and have faith in God Almighty, have a noble character, are physically and mentally healthy, able to speak, are creative in thinking, are independent and citizens who are democratic and responsible for themselves and the nation and country.

The curriculum and learning have a relationship based on an educational theory in the preparation of a learning planning strategy curriculum that includes aspects of educational theory (Suryadi, Ginanjar, \& Priyatna, 2018). In the world of education, the role of physical education is an integral part of overall education which aims to develop aspects of physical fitness, basic movement skills, critical thinking skills, social values, intelligence values reasoning, emotional intelligence, good moral values, aspects of how to live healthy in the environment. about being aligned with the overall educational goals (Herdiyana, 2016). Physical education requires a professional educator who is very good in responding to the needs of modern times along with the number of practitioners who are members of a sports and health physical education scientific group showing the level of professionalism that an educator should be able to master the material being taught, class mastery, class management, education and technology curriculum in order to achieve quality education (Winarni, 2020).

Face-to-face learning has been carried out for decades by prioritizing the process in each learning program itself. The change in the direction of education is reversed after the outbreak that made the world in an uproar, namely Covid-19 or what is commonly called the Corona Virus. This epidemic has spread to all parts of the world including Indonesia itself, which is affected by this epidemic. In March 2020 this outbreak attacked Indonesia which suddenly created a new phenomenon where every human being is prohibited from carrying out activities outside the home, it has an impact on the education process in Indonesia, the government imposes a learning process from home from all levels, from school level, elementary, junior high school, high school to college.

The implementation of e-learning allows learning from home so that students can access learning by giving assignments to the house, distance learning needs to be implemented as an introduction to the spread of the COVID-19 corona virus until it is in good condition (Supriyadi \& Dupri, 2020). Non-face-to-face education, which is called online learning, is the application of technology-based education to become a very strong reference in carrying out non-face-to-face learning activities into online learning which can be called online learning or e-learning. The use of technology is included in a study discussed by Kusama in Cendra, Gazali, and Solihin (2020).

In a situation like this, the challenge for education to face the world is that it must pay attention to the level of multimedia or information and technology development so as not to be left behind with other countries such as Germany, the United States, South Korea, China or Australia which are already familiar with online learning or e-learning in that country, and is considered very effective and right on target in learning achievement. In previous research conducted by Hanum (2013) is the implementation of e-learning at SMK Telkom Sandhy Putra Purwokerto in accordance with the quality standards of the implementation of e-learning in the learning planning component is quite effective with a tendency of $77.57 \%$; the design and material manufacturing components are quite effective with a tendency of $75.14 \%$; the delivery component of e-learning is quite effective with a tendency of $75 \%$; the interaction component of learning is quite effective with a tendency of $66.10 \%$; and the evaluation component of the implementation of e-learning is quite effective with a tendency of $69.01 \%$.

Overall, it can be concluded that the implementation of e-learning as a learning medium at SMK Telkom Sandhy Putra Purwokerto is quite effective with a tendency rate of $77.27 \%$. The results of this study illustrate that e-learning is today's learning without neglecting the achievements in every meeting. E-learning which will be held in all universities and even schools such as elementary, junior high school, high school but does not leave face-to-face learning, but can be combined between the two methods will be better for mastering in material, concept and even better skills. This is supported by previous research that has been conducted by Indarto (2019) that online learning or e-learning makes it easier for lecturers and students to interact and is easier to get information without having to do face-to-face learning.

Technological developments and advances greatly assist humans in obtaining information easily through the help of technology, so that humans can find out information from around the world. Even though it has a 
positive impact in terms of information, society must be in control in delivering the information we are looking for, in order to eliminate negative things in technology (Dupri, Nazirun, \& Risma, 2019). Along with the development of technology, the learning process has also progressed very rapidly, at this time humans are already using technology in the teaching and learning process, one example is the use of elearning in the learning process.

E-learning is learning whose implementation is supported by technology services such as telephone, audio, video tape, satellite or computer transmission (Kusumawardhani, 2016). Technology becomes a change in the need for change and innovation in the world of education that is developing in the stage of entering the 21 st century era, these changes include easy access to learning resources, making choices to utilize ICT, and increasing the role of media and multimedia in every learning process (Budiman, 2017).

Educational technology is any attempt to solve educational problems as a process or media tool that refers to future changes (Andri, 2017). Ministry of Research and Technology of the Republic of Indonesia in Budiana, Sjafirah, and Bakti (2015) argues Information and Communication Technology (ICT) as part of Science and Technology (Ilmu Pengetahuan dan Teknologi : IPTEK), in general, are all technologies related to retrieval, collection (acquisition), processing, storage, dissemination and presentation of information. Technology education itself in the current era of technology-based education or what can be called educational technology is the main thing that must be made by every intituition by reading the everdeveloping era.

According to Munir Hanum (2013) e-learning can be defined as a technology user that is carried out in an educational process that is applied in cyberspace, the term e-learning is more specifically as a form of effort to update the existing learning process in a school or college environment in a digital form bridged by technological aspects and use of the internet. The development of technological advances is the need for a concept and mechanism in learning in order to achieve aspects of technology-based education, a concept like this is known as e-learning which has an effect on the face-to-face education renewal process into the realm of digital technology which contains the main components of learning which will be accepted by the community as well as industrial progress utilizing technological facilities (Sriwihajriyah Ruskan, \& Ibrahim, 2012).

The need to develop e-learning as an alternative model of learning and learning in various educational institutions is the increasing development of the era of communication technology, infrastructure in the telecommunications sector that is side by side with the implementation of e-learning is no longer controlled by big cities, but gradually it will be easily obtained and enjoyed by all communities at the district level, which means learning in the form of a network is very likely to be applied in Indonesia (Karwati, 2014). Technology that develops in the renewal of education and ICT has a very possible and important role in the teaching and learning process, people believe that the use of multimedia will bring us to a teaching and learning situation that has an impact on face-to-face learning changes (Elyas, 2018).

College level education in the application of the teaching and learning process many have referred to the field of technology, this concept is said to be e-learning, which has made a change in the effect of changes in conventional learning, which many people say face-to-face learning will be carried out digitally, where in this learning platform is provided in an effort to align the educational process towards a better direction, and later users can easily search for information (Ucu, Paturusi, \& Sompie, 2018). According to Seok inside Sudarwati and Rukminingsih (2018) to implement e-learning in online learning now is the right time because nowadays you can take advantage of a model such as an LMS or what is commonly called a learning management system which is easily managed and installed like Moodle. E-learning solutions and strategies consist of content, technology and services. Content includes courses, curricula and knowledge or skills development modules. Technology is the method used to deliver content, including the internet and teleconferencing. Services related to maintenance, content enhancement and technical enhancements for delivery and content. Understanding these components is an important first step in understanding what elearning is and how e-learning is delivered (Sisco, 2016). In previous research conducted by Hanum (2013) is the implementation of e-learning as a learning center which is at one level of education in Purwokerto has overall results that are quite effective with a success rate of $77.27 \%$. 
The development of technological advances has an impact on the scope of education so that the use of technology is a new trend in the aspect of the scope of education in Indonesia but the platforms provided in online learning are still very limited, this can be seen from the application of technology in education which is still very small, every education is still very small optimizing face-to-face learning as well, online learning is still a very heavy homework where the application of technology-based education process is still very low.

Non-face-to-face education is a new learning that is enforced in our country, obviously it will create an interesting phenomenon to research, for this reason the researcher focuses this research at the tertiary level, with the sample being students of the Sports Education study program at the Teknokrat University of Indonesia, where researchers theirselves are active lecturers in the Sports Education study program at the Indonesian Teknokrat University. Researchers want to see the level of effectiveness of learning in the Sports Education study program, for one semester, namely in the even semester and seen from the final semester test scores of Sports Education students at the Indonesian Teknokrat University in the 2019-2020 learning year and what percentage of the pass rate is in the online learning process or e-learning.

\section{METHODS}

This research uses quantitative research methods with descriptive statistical techniques. According to Sugiyono (2015) the quantitative approach is a research method based on the philosophy of potivism, used to research on a particular population or sample. The population in this study are 210 students selected $10 \%$ by purposive sampling with a total of 21 students in the Sports Education study program at the Indonesian Teknokrat University. The subjects taken are Educational Psychology, Sports Philosophy and Sports Psychology courses. Data collection techniques use test instruments, in the form of questions and semester exam results. The research data analysis technique uses descriptive statistical techniques obtained during the 2019-2020 semester, namely the value of the Final Semester Examination, after feeling that it is enough to get the data and it is processed to get the results of the research.

\section{RESULT AND DISCUSSION}

The results of research with predetermined samples have very good results, the researchers analyze all of these subjects which are theoretical subjects taken in one even semester in 2019-2020. In the final research, it is found that $83 \%$ of students in the Sports Education study program scored above 75 , scores with a range of 60-75 are recorded at 17\%, and no students get a score below 60, it can be concluded that e-learning is accessed through spadateknokrat.ac id effective with the number of passing courses of $100 \%$.

Table 1. Students' Score

\begin{tabular}{lcccc}
\hline No & Sample & Subject 1 & Subject 2 & Subject 3 \\
\hline 1 & A & 90 & 87 & 85 \\
\hline 2 & B & 85 & 84 & 78 \\
\hline 3 & C & 82 & 68 & 70 \\
\hline 4 & D & 86 & 85 & 83 \\
\hline 5 & E & 84 & 80 & 83 \\
\hline 6 & F & 78 & 84 & 75 \\
\hline 7 & G & 76 & 80 & 82 \\
\hline 8 & H & 87 & 73 & 76 \\
\hline 9 & I & 73 & 87 & 78 \\
\hline 10 & J & 87 & 88 & 80 \\
\hline 11 & K & 83 & 78 & 83 \\
\hline 12 & L & 78 & 75 & 85 \\
\hline 13 & M & 79 & 80 & 83 \\
\hline 14 & N & 80 & 83 & 86 \\
\hline
\end{tabular}


Journal Sport Area - 6(1), 2021, 51 - 58

Aditya Gumantan., et al

\begin{tabular}{lcccc}
\hline No & Sample & Subject 1 & Subject 2 & Subject 3 \\
\hline 15 & O & 80 & 84 & 81 \\
\hline 16 & P & 74 & 88 & 85 \\
\hline 17 & Q & 68 & 90 & 83 \\
\hline 18 & R & 75 & 85 & 85 \\
\hline 19 & S & 80 & 84 & 68 \\
\hline 20 & T & 78 & 73 & 80 \\
\hline 21 & U & 78 & 82 & 78 \\
\hline
\end{tabular}

In the sample column, the research sample is explained by the initials of the alphabet letters made from A to $U$ alphabets, in order to keep the identity of the sample used in this study a secret.

Table 2. Average Score per Subject

\begin{tabular}{ccc}
\hline Subject 1 & Subject 2 & Subject 3 \\
\hline 80,05 & 81,81 & 80,33 \\
\hline
\end{tabular}

Table 1 shows the average value for subject one is 80.05 , for subject two 81.81 and subject three has an average value of 80.33. And the overall average value of the subjects is 80.73 . These results have a passing rate of $100 \%$ because in online learning in the sports education study program at the Indonesian Teknokrat University it has good content with effective learning standardization in the learning process, there are elements such as learning interactions, good learning resources, content and learning content is achieved in the form of material slides, videos and discussion forums that are class interactions so that the process can be said to be effective by understanding all the elements that have been carried out in each meeting.

This is the same as previous research conducted by Hanum (2013) that the implementation of e-learning as a learning center which is at one level of education in Purwokerto has overall results that are quite effective with a success rate of $77.27 \%$. In research conducted by Kusdianto and Sari (2019) in e-learning which is taught in a subject that is able to get a percentage gain of $88.17 \%$ which can be interpreted that it is included in the very good category which this can help students understand the concept of the material.

In spadateknokrat.ac.id, there is material content that is explained in detail with slides for teaching lecturers and is given a learning video recorded by the lecturers theirselves to discuss in detail the lecture material, in addition to material and video, there is a discussion forum column that functions to interact with questions and answers between students and lecturers if there are students who have not mastered the material well, in the last column there is a post test which is useful for measuring the level of student knowledge in each material that has been delivered. E-learning in Sports and Health Physical Education learning becomes more creative, because considering the large number of smartphone ownerships in students in this modern era, this makes learning taught to be more effective and for teachers this advantage of e-learning provides innovation for learning models which is more contemporary or modern than the material conveyed by the teacher during the lecture learning model (Prasetio, Sutisyana, Ilahi, \& Defliyanto, 2018).

It is hoped that modern learning systems such as e-learning in the future will become more effective in line with the times. Development of a learning system such as e-learning that expects not only to take into account profitability and financial issues, but also to pay attention to the psychological side of students (Silahuddin, 2015). Online learning or e-learning makes it easier for lecturers and students to interact and it is easier to get information without having to do face-to-face learning (Indarto, 2019).

\section{CONCLUSION}

This study concludes that the effectiveness of e-learning carried out in the Sports Education study program at the Indonesian Teknokrat University is very good where the passing rate in the courses taken is $100 \%$ with an average overall value of 80.73. Face-to-face learning is no longer used after the implementation of the learning from home policy by the government in March 2020 but the learning process online is currently not a big problem where the readiness of the Indonesian Teknokrat University in facing 
the learning process online has been prepared before the implementation of learning from home by government. The e-learning process continues to be developed with a better platform for the sake of facing future generations where the role of technology is a key issue in the face of changing times.

\section{REFERENCES}

Andri, R. M. (2017). Peran dan Fungsi Teknologi Dalam Peningkatan Kualitas Pembelajaran. Jurnal Ilmiah Research Sains, 3(1), 122-129.

Budiana, H. R., Sjafirah, N. A., \& Bakti, I. (2015). Pemanfaatan Teknologi Informasi dan Komunikasi Dalam Pembelajaran Bagi Para Guru SMPN 2 Kawali Desa Citeureup Kabupaten Ciamis. Dharmakarya: Jurnal Aplikasi Ipteks Untuk Masyarakat, 4(1), 59-62.

Budiman, H. (2017). Peran Teknologi Informasi Dan Komunikasi Dalam Pendidikan. Al-Tadzkiyyah: Jurnal Pendidikan Islam, 8(1), 31. https://doi.org/10.24042/atjpi.v8i1.2095

Cendra, R., Gazali, N., \& Solihin. (2020). E-learning Dalam Persepsi Mahasiswa Pendidikan Jasmani. Journal Sport Area, 5(1), 97-105. https://doi.org/10.25299/sportarea.2020.vol5(1).4721

Dupri, Nazirun, N., \& Risma, N. (2019). Penerapan Model Problem Based Learning Untuk Meningkatkan Keterampilan Berpikir Kritis Pada Pendidikan Jasmani. Journal Sport Area, 4(2), 318-326. https://doi.org/10.25299/sportarea.2019.vol4 (2).3760

Elyas, A. H. (2018). Penggunaan Model E-learning Dalam Meningkatkan Kualitas Pembelajaran. Jurnal Warta, 56(04), 1-11.

Hanum, N. S. (2013). Keefetifan e-learning sebagai media pembelajaran (studi evaluasi model e-learning SMK Telkom Sandhy Putra Purwokerto). Jurnal Pendidikan Vokasi, 3(1), 90-102. https://doi.org/10.21831/jpv.v3i1.1584

Herdiyana, A., \& Prakoso, G. P. W. (2016). Pembelajaran Pendidikan Jasmani yang Mengacu Pada Pembiasaan Sikap Fair Play dan Kepercayaan Pada Peserta Didik. Jurnal Olahraga Prestasi, 12(1), 77-85. https://doi.org/10.21831/jorpres.v12i1.9498

Hermawan, D., \& Kintamani, I. (2015). Kinerja Pendidikan Anak Usia Dini dan Pendidikan Nonformal Berdasarkan Misi Pendidikan. Jurnal Pendidikan dan Kebudayaan, 21(1), 87. https://doi.org/10.24832/jpnk.v21i1.178

Indarto, P. (2019). Model Pembelajaran Hybrit Learning Pada Mata Kuliah SepakBola di Pendidikan Olahraga FKIP UMS. JOSSAE: Journal of Sport Science and Education, 3(2), 69. https://doi.org/10.26740/jossae.v3n2.p69-75

Karwati, E. (2014). Pengaruh Pembelajaran Elektronik (E-learning) terhadap Mutu Belajar Mahasiswa. Jurnal Penelitian Komunikasi, 17(1), 41-54. https://doi.org/10.20422/jpk.v17i1.5

Kusdianto, H., \& Ika Sari, R. L. (2019). Bahan Ajar Ergosistema Berbasis E-learning Untuk Mahasiswa Program Studi Pendidikan Jasmani Kesehatan dan Rekreasi-Ibu. Multilateral Jurnal Pendidikan Jasmani dan Olahraga, 17(2), 58-62. https://doi.org/10.20527/multilateral.v17i2.5701 
Kusumawardhani, I. (2016). Poltekkes Kemenkes Yogyakarta. 4(2), 2-3.

Nurkholis. (2013). Pendidikan Dalam Upaya Memajukan Teknologi. Jurnal Kependidikan, 1(1), 24-44.

Paramitha, S. T., \& Anggara, L. E. (2018). Revitalisasi Pendidikan Jasmani untuk Anak Usia Dini melalui Penerapan Model Bermain Edukatif Berbasis Alam. Jurnal Pendidikan Jasmani dan Olahraga, 3(1), 41. https://doi.org/10.17509/jpjo.v3i1.10612

Prasetio, E., Sutisyana, A., Ilahi, B. R., \& Defliyanto, D. (2018). Tingkat Kebugaran Jasmani Berdasarkan Indeks Massa Tubuh Pada Siswa SMP Negeri 29 Bengkulu Utara. Kinestetik, 2(2), 166-172. https://doi.org/10.33369/jk.v2i2.8738

Peraturan Pemerintah Republik Indonesia. (2008). No 47 Tahun 2008 Tentang Wajib Belajar. Presiden Republik Indonesia.

Sholichah, A. S. (2018). Teori-Teori Pendidikan Dalam Al-Qur'an. Edukasi Islami: Jurnal Pendidikan Islam, 7(1), 23-46. https://doi.org/10.30868/ei.v7i01.209

Silahuddin, S. (2015). Penerapan E-learning dalam Inovasi Pendidikan. CIRCUIT: Jurnal Ilmiah Pendidikan Teknik Elektro, 1(1), 48-59. https://doi.org/10.22373/crc.v1i1.310

Sisco, A. (2016). Report May 2010 Optimizing the Effectiveness of E-learning for First Nations. May 2010.

Sriwihajriyah, N., Ruskan, E. L., \& Ibrahim, A. (2012). Sistem pembelajaran dengan e-learning untuk persiapan ujian nasional pada SMA Pusri Palembang. Jurnal Sistem Informasi (JSI), 4(1), 450-449.

Sudarwati, N., \& Rukminingsih. (2018). Evaluating e-learning as a learning media a case of entrepreneurship e-learning using schoology as media. International Journal of Emerging Technologies in Learning, 13(9), 269-279. https://doi.org/10.3991/ijet.v13i09.7783

Sugiyono. (2015). Metode Penelitian dan Pengembangan. Bandung: Alfabeta.

Supriyadi, A., \& Dupri. (2020). Peningkatan hasil belajar bolavoli dengan menggunakan sistem daring. Edu Sportivo: Indonesian Journal of Physical Education, 1(2), 112-119. https://doi.org/10.25299/es:ijope.2020.vol1(2).5609

Suryadi, E., Ginanjar, M. H., \& Priyatna, M. (2018). Penggunaan Sosial Media Whatsapp Pengaruhnya terhadap Disiplin Belajar Peserta Didik pada Mata Pelajaran Pendidikan Agama Islam (Studi Kasus di SMK Analis Kimia YKPI Bogor). Edukasi Islami: Jurnal Pendidikan Islam, 7(1), 23-46. https://doi.org/10.30868/ei.v7i01.211

Suryani, S., \& Sudarso. (2017). Pengaruh Penggunaan Metode Bagian (Part Method) Terhadap Hasil Belajar Dribble Bola Basket. Pendidikan Olahraga dan Kesehatan, 5(1), 102-109.

Sutrisno, A. (2016). Berbagai Pendekatan dalam Pendidikan Nilai dan Pendidikan Kewarganegaraan. Jurnal Dimensi Pendidikan dan Pembelajaran, 4(1), 26-37. https://doi.org/10.24269/dpp.v4i1.56

Ucu, N. L., Paturusi, S. D. E., \& Sompie, S. R. U. A. (2018). Analisa Pemanfaatan E-learning Untuk Proses Pembelajaran. Jurnal Teknik Informatika, 13(1), 1-8. https://doi.org/10.35793/jti.13.1.2018.20196 
Journal Sport đtrea - 6(1), 2021, 51 - 58

Aditya Gumantan., et al

Winarni, S. (2020). Kompetensi guru pendidikan jasmani olahraga dan kesehatan ditinjau dari usia dan jenis sekolah. Jurnal Pendidikan

Jasmani

Indonesia,

$16(1)$,

$101-114$.

https://doi.org/10.21831/jpji.v16i1.29639 